\title{
Methods of Porous Materials Obtaining from Lignin and Wood Bark
}

\author{
Boris N. Kuznetsov*a,b, \\ Nikolay V. Chesnokov ${ }^{a, b}$, Ivan P. Ivanova, \\ Evgeniya V. Veprikova ${ }^{a}$ and Natalia M. Ivanchenko ${ }^{a}$ \\ anstitute of Chemistry and Chemical Technology SB RAS \\ 50-24 Akademgorodok, Krasnoyarsk, 660036, Russia \\ ${ }^{b}$ Siberian Federal University \\ 79 Svobodny, Krasnoyarsk, 660041, Russia
}

Received 16.04.2015, received in revised form 21.05.2015, accepted 03.06.2015

Based on the analysis of sci-tech literature published in the last 5-10 years the main directions of research activity in the development of new methods of porous materials (nanoporous carbons, sorbents of oil, enterosorbents) obtaining from lignin and wood bark have been identified.

Two groups of methods are used for obtaining nanoporous carbon materials from plant biomass - two stage carbonization - physical activation and one-stage chemical activation. Two-stage method is useful for obtaining carbon sorbents from wood bark. For obtaining of nanoporous carbon materials from lignin is preferable to use the chemical activation by sodium and potassium hydroxides.

The reduction of stock of hydrolysis lignin due to the close of production facilities in Russia makes the actual searching the alternative raw materials for enterosorbents obtaining. The sorbents obtained from birch bark is not inferior to the commercial enterosorbent "Polyphepan" from hydrolysis lignin and some of their characteristics even better compared to "Polyphepan".

Keywords: lignin, wood bark, nanoporous carbon, enterosorbents, sorbents of oil, obtaining, properties.

(C) Siberian Federal University. All rights reserved

* Corresponding author E-mail address: inm@icct.ru 


\title{
Методы получения пористых материалов \\ из лигнина и древесной коры (обзор)
}

\author{
Б.Н. Кузнецов ${ }^{\text {a, }}$, Н.В. Чесноков ${ }^{\text {a, }}$, \\ И.П. Иванов ${ }^{\text {a }, ~ Е . В . ~ В е п р и к о в а ~}{ }^{\text {a }}$, Н.М. Иванченко \\ ${ }^{a}$ Институт химии и химической технологии СО РАН \\ Россия, 660036, Красноярск, Академгородок, 50/24 \\ ${ }^{6}$ Сибирский федеральный университет \\ Россия, Красноярск, 660041, пр. Свободный, 79
}

На основе анализа научно-технической литературы за последние 5-10 лет выявлены основные направления исследований в разработке новых способов получения пористых материалов из лигнина и древесной коры: получение нанопористых углеродных материалов, энтеросорбентов, нефтесобирателей.

Для получения нанопористых углеродных материалов из растительного сырья используется две группь методов: двухстадийная карбонизации - физическая активация - и одностадийная химическая активация. Двухстадийные способы целесообразно применять для получения углеродных сорбентов из древесной коры. Для получения нанопористых углеродных материалов из лигнина предпочтительным является использование химической активации гидроксидами натрия или калия.

Сокращение запасов гидролизного лигнина вследствие закрытия гидролизных производств в России делает актуальным поиск альтернативных источников сырья для получения энтеросорбентов. Доступным и дешевым ресурсом для этих изелей служит древесная кора. В частности, энтеросорбенты, полученные из березовой коры, не уступают, а по некоторым показателям превышают качество промышленного энтеросорбента «Полифепан» из гидролизного лигнина.

Ключевые слова: лигнин, древесная кора, нанопористый углерод, энтеросорбенты, нефтесобиратели, получение, свойства.

\section{Введение}

Производство и потребление пористых материалов имеет устойчивую тенденцию к росту. В частности, мировое потребление пористых углеродных материалов (ПУМ) составляет около 1,1 млн тонн в год и продолжает расти на 9 \% в год [1]. При этом основное количество активированных углей (80-85 \%) производится из невозобновляемых ресурсов. Большой ассортимент ПУМ можно получать на основе крупнотоннажных отходов химической и механической переработки древесины: опилок, коры, отходов лесозаготовок и технических лигнинов.

В настоящее время основные направления использования углеродных сорбентов связаны с технологическими процессами адсорбционной очистки, разделения, выделения и концен- 
трирования в газовых и жидких средах. Постоянно возрастает роль углеродных сорбентов в решении экологических проблем: при очистке питьевой воды, стоков, отходящих газов предприятий промышленности и энергетики. Расширяются области использования углеродных сорбентов в медицине и фармацевтике. Так, например, углеродные гемосорбенты применяют для очистки крови у больных, а энтеросорбенты - внутрь в целях очистки организма от вредных веществ и микробов.

Сорбенты используются в различной форме: в виде порошка с размером частиц до 0,8 мм, гранул более крупного размера, блоков различной формы и величины, пленок, волокон тканей. Наиболее распространены порошкообразные сорбенты, которые достаточно просто получать из измельченного сырья.

Пористый углеродный материал (ПУМ) представляет собой конструкцию, построенную подобно структуре графита, однако в ней чередуются упорядоченные и неупорядоченные области из углеродных колец - гексагонов. В отличие от графита ПУМ обладает свободным пористым пространством, которое обычно представлено трехмерным лабиринтом из взаимосвязанных расширений и сужений различного размера и формы. Различают микропоры (размер $\leq 2$ нм), мезопоры (размер в диапазоне от 2 до 50 нм) и макропоры с размером $>50$ нм. Среди микропор выделяют супермикропоры с размером в диапазоне 0,7-2 нм и ультрамикропоры с размером < 0,6-0,7 нм. Благодаря наличию пор ПУМ имеют высокую удельную поверхность и способны поглощать (адсорбировать) различные вещества из жидкостей и газов.

Способность ПУМ к адсорбции различных молекул определяется строением его поверхности, природой и концентрацией поверхностных реакционноспособных групп. В качестве последних обычно выступают кислородсодержащие функциональные группы, образующиеся в результате окислительной обработки поверхности углеродного материала: фенольные (гидроксильные), карбонильные (хиноидные), карбоксильные, эфирные, енольные, лактонные. При соответствующих условиях синтеза и обработки ПУМ на их поверхности возможно получение функциональных групп, содержащих азот, серу, галогены, фосфор.

Пористые углеродные материалы образуются в результате протекания топохимических реакций при пиролизе (нагреве в отсутствие кислорода воздуха) ископаемых углей, торфа, древесины, целлюлозы. В настоящее время из древесины производят около 36 \% углеродных сорбентов, из каменных углей - 28 , из бурых углей - 14, из торфа - 10, из скорлупы кокосовых орехов - около $10 \%$.

Разработаны различные технологии получения ПУМ из твердого органического сырья, которые основаны на методах физической и химической активации [2].

Процессы физической активации, как правило, осуществляются в два этапа, включающих карбонизацию сырья и активацию карбонизованного продукта водяным паром или диоксидом углерода.

Химическая активация основана на одностадийной термообработке исходного углеродного сырья химическими веществами $\left(\mathrm{H}_{3} \mathrm{PO}_{4}, \mathrm{KOH}, \mathrm{NaOH}, \mathrm{ZnCl}_{2}\right.$ и др.) При этом процессы карбонизации и активации сырья протекают одновременно. Использование химической активации обычно приводит к образованию пористых углеродных материалов с более высокой поверхностью и объемом микропор, чем при физической активации. 


\section{1. Получение пористых материалов из лигнина}

По распространенности в природе лигнин стоит на втором месте после целлюлозы и является растительным полимером ароматической природы.

Рост суммарного производства лигнина (более 50 млн т/г) сопровождается увеличением интереса к разработке новых экономически эффективных технологий его переработки. В современных условиях большая часть технических лигнинов используется в качестве топлива. Хотя есть и некоторые направления их малотоннажного использования $[3,4]$.

Возможности применения лигнина для получения сорбентов наиболее широко изучены для технических лигнинов, в частности щелочных лигнинов (образуются от варки древесины в растворах щелочей), лигносульфонатов (образуются при сульфитной варке древесины) и гидролизных лигнинов (образуются при кислотом гидролизе древесины) $[5,6]$.

Актуальность разработки новых технологий получения недорогих и эффективных ПУМ обусловлена потребностями в них различных отраслей промышленности. Они применяются для очистки технологических растворов и воды, разделения и выделения металлов, при синтезе лекарственных препаратов, получении напитков, в охране окружающей среды. Кроме того в настоящее время появляются принципиально новые направления применения ПУМ, а именно при изготовлении суперконденсаторов, аккумуляторных батарей высокой мощности, в которых наряду с электролитами большое влияние на мощность и скорость зарядки оказывает внутренняя поверхность углеродных материалов.

В статье на основе анализа научной и патентной литературы, опубликованной в течение последних 5-10 лет, выявлены основные направления исследований в разработке новых способов получения из лигнина и древесной коры востребованных нанопористых углеродных материалов, энтеросорбентов, нефтесобирателей.

\section{Углеродные сорбенты из лигнина}

Определенную роль в формировании пористой структуры углеродных сорбентов играют условия термической обработки технических лигнинов.

В работе [7] исследован процесс пиролиза сульфатного лигнина в интервале температур 200-900 ${ }^{\circ} \mathrm{C}$. Обнаружено, что термохимические превращения крафт-лигнина происходят на протяжении всего температурного интервала, хотя наиболее значимые изменения наблюдаются при температурах $500-600{ }^{\circ} \mathrm{C}$.

Гидролизный лигнин может быть пиролизован в микропористый углерод с выходом 50 \% при нагревании до $900{ }^{\circ} \mathrm{C}$ без активации в токе аргона [8]. Карбонизованный материал, полученный при скорости нагрева $1{ }^{\circ} \mathrm{C} /$ мин, имел удельную площадь поверхность $530 \mathrm{~m}^{2} /$, которая увеличилась до 740 м²/г после промывки углеродного продукта водой.

При пиролизе щелочного лигнина в токе аргона до температуры $900{ }^{\circ} \mathrm{C}$ образуется микропористый углерод с выходом 50 \% [9]. Щелочной лигнин был предварительно структурирован в виде частиц микронного размера путем мицеллообразования и гелеобразования. Карбонизация структурированных лигнинов позволяет получать высокопористые материалы, обладающие площадью поверхности более 1000 м²/г, без использования процессов активации.

Изучен процесс формирования микротекстуры в углеродных сорбентах, полученных карбонизацией гранул гидролизного лигнина при $300-1300{ }^{\circ} \mathrm{C}$ и последующей парогазовой акти- 
вацией при $800{ }^{\circ} \mathrm{C}$. В результате были получены нанопористые углеродные материалы с узким распределением пор по размерам (в диапазоне $0,7-0,9$ нм) и величиной удельной поверхности до $750 \mathrm{M}^{2} /$ г.

Кратковременной (несколько секунд) термообработкой измельченного гидролизного лигнина в псевдоожиженном слое оксидного $\mathrm{Al}-\mathrm{Cu}-\mathrm{Cr}$ катализатора при температурах $670-820{ }^{\circ} \mathrm{C}$ получены ПУМ с развитой пористой структурой [10]. Сорбционная емкость углеродных продуктов в отношении йода и реакционная способность при активации водяным паром определялись режимными параметрами процесса термообработки лигнина. Осуществлен подбор условий карбонизации гидролизного лигнина и активации углеродного продукта, обеспечивающих получение качественных ПУМ (объем пор $0,9 \mathrm{~cm}^{3} / \Gamma$, удельная поверхность $750-800 \mathrm{~m}^{2} / \Gamma$ ) с выходом 15-19 \% относительно массы сухого лигнина.

Изучено влияние режимов карбонизации и последующей активации водяным паром на микроструктуру и молекулярно-ситовые свойства гранулированных пористых углеродных материалов, полученных из гидролизного лигнина [11]. Установлено, что малая скорость нагрева (менее $3{ }^{\circ} \mathrm{C} /$ мин) способствует образованию в углеродном продукте микропор со средним размером около 0,56-0,58 нм при температуре карбонизации $700{ }^{\circ} \mathrm{C}$. При этих же условиях, но скорости нагрева более $3{ }^{\circ} \mathrm{C} / \mathrm{мин,} \mathrm{образуются} \mathrm{микропоры} \mathrm{со} \mathrm{средним} \mathrm{размером} \mathrm{пор}$ $0,70-0,78$ нм. Активация угля из лигнина водяным паром при $800^{\circ} \mathrm{C}$ приводит к формированию АУ с более развитым объемом микропор и шириной 0,6-0,66 нм. Эти активные угли обладают молекулярно-ситовыми свойствами и способны отделять гелий от метана в смесях $\mathrm{He}-\mathrm{CH}_{4}$.

В качестве прекурсора для приготовления активированного угля методом парогазовой активации был использован черный щелок целлюлозно-бумажного производства [12]. Оптимизированные условия получения качественного активированного угля на основе лигнина включают предварительную карбонизацию лигнин-содержащего щелока при температуре $450{ }^{\circ} \mathrm{C}$ в течение 60 мин и последующую активацию паром при $725^{\circ} \mathrm{C}$ в течение 40 мин. Были получены активированные угли с максимальной адсорбционной емкостью по метиленовому синему $92,5 \mathrm{мг} / \mathrm{\Gamma}$.

Активация карбонизованного крафт-лигнин эвкалипта при $850{ }^{\circ} \mathrm{C}$ в течение 20 ч в токе $\mathrm{CO}_{2}$ позволяет получить активные угли с удельной поверхностью до $1853 \mathrm{~m}^{2} / \Gamma$ с объемом микропор до $0,57 \mathrm{~cm}^{3} / \Gamma[13]$.

Путем карбонизации гидролизного лигнина при $600-700{ }^{\circ} \mathrm{C}$ получены микропористые ПУМ с минимальным средним размером микропор [14]. При последующей парогазовой активации карбонизированных образцов лигнина происходит «растравливание» микропор с получением активных углей с удельной поверхностью $865 \mathrm{~m}^{2} / \Gamma$ и объемом микропор $0,37 \mathrm{~cm}^{3} / \Gamma$.

В работе [15] установлено, что значительное сокращение продолжительности процесса активации в токе $\mathrm{CO}_{2}$ при $750{ }^{\circ} \mathrm{C}$ может быть достигнуто при пропитке крафтлигнина $\mathrm{NaCl}$ или $\mathrm{KCl}$. Контролируя условия процесса, можно получить преимущественно ультрамикропористые материалы со средней шириной пор $0,53-0,77$ нм и объемом пор до $0,82 \mathrm{~cm}^{3} / \Gamma$.

В настоящее время при синтезе ПУМ все шире используются методы химической активации [16]. Преимуществами этих методов являются сокращение продолжительности активирования сырья, повышенный выход ПУМ и их высокие адсорбционные свойства.

$$
-236-
$$


Различные типы ПУМ были приготовлены термообработкой лигнина, модифицированного $\mathrm{H}_{3} \mathrm{PO}_{4}$, при температурах карбонизации $\left(300-600{ }^{\circ} \mathrm{C}\right)$ [17-19]. Полученные ПУМ имеют площадь поверхности до $700 \mathrm{~m}^{2} / \Gamma$, объем микро- и мезопор варьируется от 0,06 и 0,45 cм³/г. Активность полученных ПУМ в сорбции ионов металлов (никеля, железа, хрома и кремния) и фенольных соединений сравнима с активностью углеродных сорбентов. Также они могут эффективно использоваться для удаления красителей из водных растворов.

Показана возможность применения этих ПУМ из лигнина в сорбционных процессах удаления $\mathrm{Cu}$ (II) из промышленных сточных вод [19]. А также возможность использования высокопористого активированного угля, получаемого из технического лигнина микроволновой обработки при температуре $600{ }^{\circ} \mathrm{C}$, для сорбции эндосульфана [20].

Активированные угли с высокой удельной поверхностью (до $3089 \mathrm{~m}^{2} / г$ ) и объемом пор (до $1,7 \mathrm{~cm}^{3} / \Gamma$ ) получены путем карбонизации черного щелока при $600{ }^{\circ} \mathrm{C}$ в присутствии КОН и последующей паровой активации при температуре $900{ }^{\circ} \mathrm{C}$ [21]. Натрий и калий, присутствующие в исходном черном щелоке, выступают в качестве активирующих агентов.

В работах $[22,23]$ представлена возможность получения путем термохимической активации гидролизного лигнина с гидроксидом натрия и калия при $800{ }^{\circ} \mathrm{C}$ ПУМ универсального типа, пригодных для использования в различных областях.

В работе [24] изучен процесс формирования пористой структуры активированных углей на основе хлопкового гидролизного лигнина и установлены зависимости между пористой структурой ПУМ и их адсорбционной активностью в отношении ряда токсинов. Показано, что карбонизация является наиболее важной стадией формирования пористой структуры и свойств активированных углей из хлопкового лигнина, причем наиболее эффективные углеродные сорбенты получены активацией карбонизованного при $800{ }^{\circ} \mathrm{C}$ лигнина.

Перспективные направления переработки гидролизного лигнина связаны с его модификацией, в процессе которой в лигнин вводятся новые функциональные группы, меняются его структура и молекулярная масса. Предложены различные методы активации и модификации гидролизного лигнина: щелочная активация, карбоксиметилирование, аминирование, термообработка на разных стадиях модификации [25].

В работе [26] указаны возможности использования гидролизного лигнина в качестве катодного материала для первичных литиевых источников тока. В качестве электродных материалов взят активированный уголь, полученный путем карбонизации коммерческого лигнина (Aldrich), а затем активирован КОН в соотношении 1:4. Полученный активированный уголь является микропористым и имеет удельную поверхность до 2300 м²/г.

Изучено формирование структуры пористых углеродных материалов, получаемых щелочной термоактивацией уксусно-кислотного лигнина, выделенного из соломы пшеницы, с использованием метода окислительной каталитической делигнификации [27]. Вследствие одновременно протекающих термоинициируемых реакций взаимодействия щелочного компонента с функциональными группами лигнина, а также процессов конденсации и деполимеризации формируется развитая нанопористая структура карбонизованного продукта. Установлено влияние природы щелочи на строение и сорбционные свойства получаемых нанопористых углеродных материалов (НУМ). Осуществлен подбор условий щелочной термоактивации, позволяющих синтезировать НУМ с уникально высокой удельной поверхностью (до 3000 м²/г).

$$
-237-
$$


Активацией лигнина, выделенного из черного щелока, в присутствии $\mathrm{FeCl}_{3}$ получен высокостабильный катализатор $\mathrm{Fe} /$ улерод для очистки воды от органических примесей [28]. Активированные угли, приготовленные путем активации лигнина $\mathrm{ZnCl}_{2}$, предложено использовать в качестве адсорбента для удаления метилового оранжевого из воды и сточных вод [29].

Для получения активированного угля из лигнина, выделенного из стеблей кукурузы, предложено использовать стадии высокоскоростного пиролиза в кипящем слое при $350{ }^{\circ} \mathrm{C}$ и последующей активации карбонизата в смеси с $\mathrm{K}_{2} \mathrm{CO}_{3}$ при температуре $800{ }^{\circ} \mathrm{C}$ в течение 60 мин [30]. Полученный углеродный материал с удельной поверхностью $1410 \mathrm{~m}^{2} / \Gamma$ и объемом пор $0,77 \mathrm{~cm}^{3} / \Gamma$ активен в сорбции фенола.

В работе [31] представлены результаты исследования высокопористых субмикронных активированных углеродных волокон, полученных термоактивацией КОН щелочного лигнина. Активированные волокна обладают высокими гидрофильными характеристиками и высокой удельной поверхностью. Они были использованы в качестве суперконденсаторов емкостных накопителей энергии и после 5000 циклов зарядки/разрядки сохраняли свыше 96 \% первоначальной емкости.

В работе [32] изучена структура ПУМ, полученных методом щелочной термоактивации различных лигнинов. Установлены оптимальные условия получения углеродных материалов с узкими микропорами, а именно активация при температурах $550-650{ }^{\circ} \mathrm{C}$, соотношение гидроксид/лигнин $=1$ и продолжительность выдержки при температуре активации 30 мин. Обнаружено, что применение КОН предпочтительнее, чем $\mathrm{NaOH}$, так как позволяет снизить температуру активации и повысить выход ПУМ.

Нанопористые углеродные материалы с высокой удельной поверхностью (более $2400 \mathrm{~m}^{2} / \Gamma$ ) были получены путем термической обработки смеси крафт-лигнина и гидроксида натрия [33].

Следует выделить ряд публикаций, посвященных разработке новых способов получения энтеросорбентов на основе лигнина $[34,35]$. Установлено, что сульфатные лигнины из щелоков делигнификации хвойной и лиственной древесины способны прочно связывать микотоксины и могут найти применение в ветеринарной энтеросорбции. Лигнины, осажденные из щелока варки хвойных пород (ель, смесь ели и сосны), по своим сорбционным свойствам не уступают энтеросорбенту «Фильтрум СТИ» на основе гидролизного лигнина. По сорбции микотоксинов и прочности их связывания эти лигнины не уступают «Полифепану» и могут быть рекомендованы для профилактики микотоксикозов животных [34, 35].

В литературе описаны свойства энтеросорбентов, полученных из лигнинов древесины пихты, осины и березы. Лигнины выделяли путем обработки древесного сырья смесью «уксусная кислота - вода - пероксид водорода - сернокислотный катализатор» [36]. Для получения энтеросорбентов с оптимальным сочетанием выхода и сорбционных свойств лигнины предложено обрабатывать $0,4 \%$-ным раствором $\mathrm{NaHCO}_{3}$ при комнатной температуре в течение 15 мин. Выход энтеросорбентов, полученных в этих условиях, составляет 73-76 \%. Их сорбционная емкость по метиленовому синему и желатину равна 88-89 и 183-212 мг/г соответственно. По сорбционной активности маркерных веществ энтеросорбенты на основе лигнинов пихты, осины и березы превосходят промышленный энтеросорбент марки «Полифепан» [37]. 


\section{2. Получение пористых материалов из коры}

Получение энтеросорбентов

В медицинской и ветеринарной практике используются минеральные, углеродные и углеродминеральные энтеросорбенты. Высокую эффективность проявляют безопасные для живого организма энтеросорбенты из природного растительного сырья. К их числу относится полифепан - энтеросорбент, производимый из гидролизного лигнина.

Аналоги полифепана могут быть получены и из других видов сырья растительного происхождения, в частности из твердых остатков экстракционной переработки древесной коры. Удаление экстрактивных веществ, находящихся в порах растительного сырья, способствует формированию развитой пористой структуры в твердом остатке экстракции.

В работе [38] в качестве исходного сырья для получения сорбентов использовали луб коры березы повислой (Betula pendula Roth.) следующего состава (\%): полисахариды 49,09 \% (из них легкогидролизуемых полисахаридов 26,29, трудногидролизуемых 22,36, лигниновых веществ 34,82, водорастворимых 13,71, минеральных 3,42).

Сорбенты получали обработкой 1-2 \%-ным раствором $\mathrm{NaOH}$ березовой коры [39] или луба березовой коры [40], предварительно измельченных до частиц размером от 0,1 до 1 мм.

В работах $[41,42]$ описана возможность получения энтеросорбента ветеринарного назначения из коры ивы Salix acutifolia. Кору предложено обрабатывать ферментным комплексом целлюлазы и р-глюканазы при температуре $35^{\circ} \mathrm{C}$ в течение 9 часов. Расход ферментного комплекса составляет 0,1 \% от массы коры. В результате реализации предлагаемого способа возможно получать два целевых продукта: биоактивный препарат - салицилат и энтеросорбент. Установлено, что энтеросорбент из коры ивы характеризуется высокой сорбционной емкостью и удерживающей способностью в отношении микотоксина Т-2, который может попадать в организм животных и птиц с некачественными кормами [42].

Предложен способ получения энтеросорбента из коры березы, включающий обработку сырья 0,5-2\%-ным раствором щелочи при температуре $60-100{ }^{\circ} \mathrm{C}$, гидромодуле $4-7$, в течение 30-60 мин., промывку водой, нейтрализацию и сушку до воздушно-сухого состояния [43]. Полученный энтеросорбент по сорбции метиленового синего и желатина превосходит «Полифепан» в 2,5 и 1,5 раза соответственно [43].

Качество получаемых образцов энтеросорбентов оценивали по их способности поглощать широко используемые для этих целей вещества-маркеры: йод и метиленовый синий, которые моделируют класс низкомолекулярных токсикантов (креатинин, мочевая кислота, барбитураты и другие с молекулярной массой до 500 а.е.м.), а также по адсорбции билирубина, который используется в клинических исследованиях как маркер печеночной недостаточности.

Было изучено влияние условий предварительной экстракции луба гексаном, этилацетатом, изопропанолом и водой, а также обработки исходного и проэкстрагированного луба разбавленным раствором гидроксида натрия. Выход сорбента при щелочной обработке исходного луба составлял 41-42 \% от веса исходного сырья. Более высокий выход сорбента в расчете на исходное сырье (67-71 \%) был получен при щелочной обработке твердого остатка, полученного в процессе последовательной экстракции луба гексаном, этилацетатом и водой. Образец, полученный обработкой предварительно проэкстрагированного луба $2 \%$-ной $\mathrm{NaOH}$ при $60{ }^{\circ} \mathrm{C}$ в течение 1-2 ч, обладает наиболее высокой сорбционной способностью.

$$
-239-
$$


Результаты сопоставления сорбционных характеристик энтеросорбента, полученного из луба березовой коры и промышленного энтеросорбента полифепана (производитель АО «Сантек», Санкт-Петербург, Р№ 001047/03-2002 г.), показали, что сорбенты, полученные щелочной обработкой проэкстрагированного луба, превосходят полифепан по способности адсорбировать метиленовый синий более чем в 4 раза, но несколько уступают ему в адсорбции йода.

Для оценки детоксикационной способности по отношению к эндотоксинам пептидной природы изучена сорбция билирубина из модельных растворов на сорбентах из луба березовой коры. Билирубин является конечным продуктом распада гемоглобина, входит в состав желчи и придаёт ей характерную окраску. Экспериментальные результаты по сорбции билирубина энтеросорбентами свидетельствуют о том, что наиболее существенное влияние на ёмкость сорбента по билирубину оказывает обработка образца $0,1 \mathrm{M}$ соляной кислотой, которая приводит к увеличению его сорбции примерно в два раза. Взятые в качестве образцов сравнения промышленные сорбенты марки «Полифепан» имеют весьма низкую активность в сорбции билирубина.

Сорбенты из луба березовой коры, полученные при его обработке $\mathrm{NaOH}$, обеспечивают примерно 50\%-ную очистку растворов от билирубина. Использование дополнительной кислотной обработки сорбента из луба позволяет при определённых условиях увеличить этот показатель практически до $100 \%$.

Показано, что предварительная активация коры березы взрывным автогидролизом позволяет существенно увеличивать сорбционную активность энтеросорбентов по метиленовому синему и желатину [43]. Определены условия взрывного автогидролиза коры березы и содержание бересты в сырье, которые обеспечивают сочетание высокой сорбции этих маркеров энтеросорбентом: температура $190{ }^{\circ} \mathrm{C}$, давление пара 2,5 МПа, время обработки 30 с; содержание бересты около $25 \%$. Такой энтеросорбент по величине сорбционной емкости по отношению к метиленовому синему и желатину превосходит промышленный энтеросорбент «Полифепан» в 2,5 и 1,5 раза соответственно.

\section{Нефтяные сорбенть}

Материалы, применяемые для сбора нефти и нефтепродуктов с поверхности водоемов, принято называть нефтяными сорбентами, а также нефтесобирателями и нефтепоглотителями. Для определения качества нефтяных сорбентов используют три основных показателя: нефтепоглощение, водопоглощение, плавучесть. Эффективность сорбентов для сбора нефти оценивают в первую очередь по значению нефтеемкости. Высокое водопоглощение можно устранить практически для всех материалов дополнительной гидрофобизацией. Материалы с низкой плавучестью могут эффективно использоваться в изделиях с армирующей оболочкой бонах, матах, салфетках и др. [44, 45]. Для производства нефтяных сорбентов применяют разнообразное сырье [46, 47].

Особый интерес представляют доступные и дешевые ресурсы растительных отходов, в частности древесной коры. Для повышения сорбционной способности растительного сырья используют различные методы активации, например мехобработки и взрывного автогидролиза. В литературе имеются сведения об использовании сорбентов из древесной коры для очистки воды от нефтепродуктов, красителей, тяжелых металлов [48-52]. 
Метод взрывного автогидролиза был использован для получения сорбционно-активных материалов из коры различных пород деревьев. Оптимальные условия автогидролиза, обеспечивающие максимальное поглощение нефти и моторного масла, следующие: для сосновой коры - $140{ }^{\circ} \mathrm{C}, 3 \mathrm{MПа,} 90$ с; для бересты $-170{ }^{\circ} \mathrm{C}, 2,5 \mathrm{MПа,} 60 \mathrm{c}$; для коры и окорки осины $200{ }^{\circ} \mathrm{C}, 4 \mathrm{M \Pi а}, 60 \mathrm{c}$.

Автогидролиз образцов коры приводит к существенному увеличению их нефтеемкости и маслоемкости. Лучшие показатели демонстрируют образцы сорбентов из бересты и окорки осины. Сорбенты из опилок, коры и окорки осины и березовой бересты, полученные автогидролизом, не уступают промышленному сорбенту из торфа «Пит Сорб» (ФРГ, «Клон Инк.»).

Сорбенты из коры и окорки осины, бересты характеризуются также высокой способностью к регенерации собранной нефти механическим отжимом. Следует отметить, что по степени отжима нефти сорбент из бересты превосходит образец сравнения.

Установлено, что нефтеемкость всех исследованных сорбентов из древесных отходов после отжима не превышает 5-10 \% от начального значения, что обуславливает возможность их многоразового применения.

Таким образом, метод взрывного автогидролиза позволяет получать из древесной коры сорбенты с хорошими показателями сорбционной емкости по нефтепродуктам и степени их отжима. Благодаря высокой плавучести после сбора нефти и незначительной степени нефтеотдачи эти сорбенты могут эффективно использоваться для ликвидации загрязнений с водных поверхностей.

Эффективными нефтесобирателями являются синтетические волокнистые материалы. Они легко и быстро размещаются на местах разливов нефти и собираются после пропитывания, а также характеризуются возможностью многократного использования после отжима нефти [53].

В качестве волокнистых сорбентов все шире применяют композиционные материалы, при получении которых в качестве наполнителя используют различные растительные отходы. Известно, что в таких материалах удается сочетать значительную степень замещения синтетического материала (до 45 \% и выше) и высокие показатели нефтеемкости [54, 45]. Кроме того, доступность и дешевизна растительных наполнителей позволяют значительно снизить себестоимость синтетических композитов, что стимулирует их широкое применение для решения экологических задач.

В работе [55] в качестве полимерного компонента для приготовления сорбента брали гранулы вспененного полистирола, который получали из бисера марки ПСВ-С (диаметр 1 мм, ОСТ 301-05-202-92Е) по методике, применяемой для производства промышленного пенопласта, и крошку (размер 3-5 мм) бытовых отходов полистирольного пенопласта. В качестве древесных наполнителей использовали измельченную кору осины, окорку осины (содержание коры и древесины 1:1) и осиновые опилки, а также кору сосны и бересту березы.

\section{Получение углеродных сорбентов}

Экономическая целесообразность переработки отходов древесной коры в углеродные сорбенты (активные угли) определяется возрастающими масштабами их использования и достаточно высокой стоимостью. При существующих ценах на качественные углеродные сорбенты 
экономическая эффективность их производства в расчете на 1 т перерабатываемой коры значительно выше, чем при использовании коры в качестве топлива.

Конкурентоспособность технологий переработки отходов коры в активные угли можно повысить, применяя новые технические решения. В частности, был использован более экономичный, чем традиционный паровой, способ термоактивации коры смесью дымовых газов и водяного пара, положительно себя зарекомендовавший при переработке других видов древесного сырья.

Эксперименты по термообработке исходной пихтовой коры, проэкстрагированной гексаном, и остатка коры после последовательной экстракции гексаном и изопропиловым спиртом производились на укрупненной лабораторной установке, моделирующей термические режимы промышленного аппарата псевдоожиженного слоя, обеспечивающего совмещение процессов пиролиза и активации [56].

Для оценки влияния концентрации кислорода в активирующем агенте на адсорбционные характеристики получаемых активных углей была изучена активация карбонизованной при $600{ }^{\circ} \mathrm{C}$ пихтовой коры. Установлено, что наличие кислорода в активирующем агенте при его концентрациях 1-2 \% слабо влияет на сорбционные свойства получаемых углеродных продуктов. При более высоком содержании кислорода в активирующей смеси наблюдается существенное снижение сорбционной активности получаемых активных углей. Следует отметить, что при концентрации кислорода в смеси, равной $1 \%$, был получен активный уголь с максимальной сорбционной активностью по фенолу [56].

Адсорбционная способность активированных углей по йоду слабо зависит от условий экстракции коры и варьируется от 62 до 79 \%. Эти значения соответствуют характеристикам современных промышленных углеродных сорбентов.

Адсорбционная способность по метиленовому голубому увеличивается по мере возрастания количества стадий экстракционной обработки коры. Этот факт в сочетании с достаточно высокой сорбционной активностью углей из пихтовой коры по фенолу позволяет рекомендовать данные образцы сорбентов для очистки воды от фенолов и близких им по свойствам органических веществ.

Образующиеся отходы коры лиственницы имеют широкий полидисперсный состав. Однако для получения качественных углеродных сорбентов предпочтительно использование сырья однородного фракционного состава. В этой связи подготовка коры для дальнейшей переработки предполагает наиболее приемлемые технологические варианты - агломерацию или фракционирование.

В работе [57] изучен процесс получения углеродных сорбентов из брикетированной коры лиственницы с использованием традиционной технологии слоевой карбонизации брикетов в реакторе с внешним обогревом в условиях низкоскоростного пиролиза $\left(2{ }^{\circ} \mathrm{C} / \mathrm{Mин}\right)$, изотермической выдержке при $550^{\circ} \mathrm{C}$ в течение 1 ч и последующей слоевой парогазовой активации при $850{ }^{\circ} \mathrm{C}$. Авторы указывают, что в результате активации поверхностный слой брикетов оказался «переугленным», а полученные сорбенты имели неоднородные характеристики [58]. Кроме того, введение дополнительной технологической стадии брикетирования в сочетании с низкопроизводительной слоевой технологией пиролиза и активации увеличивает общую продолжительность процесса (более 6 ч) и существенно повышает себестоимость сорбентов. 
В сравнении со слоевыми процессами установки псевдоожиженного слоя характеризуются более высокими коэффициентами тепло- и массообмена, широтой диапазона варьирования основных параметров процесса, а также легкой адаптируемостью к изменению свойств исходного сырья. При этом в качестве активирующего агента возможно использование дымовых газов, образующихся при пиролизе древесины, основным компонентом которых является диоксид углерода.

В работах $[59,60]$ представлена возможность получения качественных углеродных сорбентов из коры лиственницы и пихты парогазовой активацией угля-сырца при $850{ }^{\circ} \mathrm{C}$ в реакторе псевдоожиженного слоя. Однако использованный уголь-сырец также был получен низкоскоростным слоевым пиролизом коры.

В работе [61] изучено влияние условий процесса совместной карбонизации-активации зерненной коры лиственницы в реакторе псевдоожиженного слоя на пористую структуру и сорбционные свойства получаемых углеродных сорбентов.

Обнаружено, что повышение температуры карбонизации от 500 до $700{ }^{\circ} \mathrm{C}$ и продолжительность изотермической выдержки при выбранной температуре от 30 до 60 мин снижает выход угля-сырца из коры лиственницы.

Значительное влияние на выход угля-сырца оказывает скорость нагрева коры в процессе пиролиза. Так, в условиях низкоскоростного пиролиза (5 $\left.{ }^{\circ} \mathrm{C} / \mathrm{Mин}\right)$ повышение температуры карбонизации коры от 500 до $700{ }^{\circ} \mathrm{C}$ приводит к снижению выхода угля с 64,3 до 56,9 \% мас. при изотермической выдержке 30 мин. Увеличение скорости нагрева коры на стадии пиролиза до $80{ }^{\circ} \mathrm{C} /$ мин приводит к повышению выхода летучих веществ, которые не участвуют в формировании первичной структуры карбонизованного продукта. В этой связи снижение выхода угля-сырца оказывается более существенным по сравнению с низкоскоростным пиролизом во всем исследованном диапазоне температур. Так, при высокоскоростном нагреве до температуры карбонизации $500{ }^{\circ} \mathrm{C}$ и продолжительности выдержки 30 мин выход угля составил 40,7 \% мас.

Первичная структура пористых углеродных материалов, формируемая на стадии карбонизации древесного сырья, оказывает существенное влияние на формирование вторичной пористой структуры при воздействии активирующими агентами.

Развитие пористой структуры активных углей сопровождается снижением их механической прочности. Результаты измерения распределения частиц по размерам показали, что при увеличении скорости нагрева зерен коры лиственницы в псевдоожиженном слое с 5 до $80{ }^{\circ} \mathrm{C} /$ мин приводит к уменьшению размера частиц основной фракции сорбентов с 1,5-2,0 до $1,0-1,5$ мм.

Установлены основные закономерности формирования пористой структуры углеродных адсорбционных материалов, получаемых из коры лиственницы сибирской и твердых остатков ее экстракционной переработки [60]. Показано, что при последовательной экстракции коры различными растворителями образуется разрыхленная древесная структура, легко подвергающаяся пиролизу при температуре $650{ }^{\circ} \mathrm{C}$. В дальнейшем образующийся углеродный материал путем парогазовой активации при $800{ }^{\circ} \mathrm{C}$ доводится до уровня показателей промышленных древесных АУ.

Изменение текстуры полученных АУ по мере роста числа стадий экстракционной обработки коры происходит в направлении увеличения удельной поверхности и объема мезопор за

$$
-243-
$$


счет растравливания микропор и выгорания мезопор до размеров микропор. Показана возможность получения адсорбционных материалов с различной пористой структурой из коры лиственницы путем варьирования условий ее предварительной экстракционной обработки. Эти сорбенты можно использовать во многих технологических схемах. Порошковые материалы, полученные из коры, близки по характеристикам к осветляющим активным углям типа ОУ и их зарубежным аналогам.

В работе [62] исследовали синтез пористых углеродных материалов из коры чайного дерева с использованием в качестве активирующего агента КОН и их применение в качестве сорбционного материала для хранения водорода. Для активации применяли разные количества $\mathrm{KOH} \mathrm{и} \mathrm{исследовали} \mathrm{их} \mathrm{влияние} \mathrm{на} \mathrm{развитие} \mathrm{микропористости} \mathrm{получаемых} \mathrm{продуктов} \mathrm{и}$ сорбционной емкости по водороду. Кору чайного дерева предварительно обрабатывали $1 \mathrm{M}$ раствором КОН. Высушенная кора была карбонизована при 1073 K в течение 4 ч в атмосфере азота. Карбонизованные образцы промывали 3 М раствором соляной кислоты для удаления неорганических примесей и дистиллированной водой до нейтрального $\mathrm{pH}$ и высушивали при $393 \mathrm{~K}$ до постоянного веса. Полученные образцы активированной коры имели высокую площадь поверхности (до 3170 м²/г) и большую сорбционную емкость по водороду (4,08 \% мас. при 77 K и 10 бар).

В работах [63-65] в качестве сырья для получения активированного угля использовали кору эвкалипта. Высушенную при $105{ }^{\circ} \mathrm{C}$ кору пропитывали фосфорной кислотой (85 мас. \%) при различном весовом соотношении коры и кислоты, а затем карбонизовали в муфельной печи при $500{ }^{\circ} \mathrm{C}$ в течение 1 ч. Установлено, что активированные угли с лучшей адсорбционной способностью были получены при температуре активации $500{ }^{\circ} \mathrm{C}$ при продолжительности 1 ч и соотношении пропитки 1:1. Полученный активированный уголь характеризуется следующи-

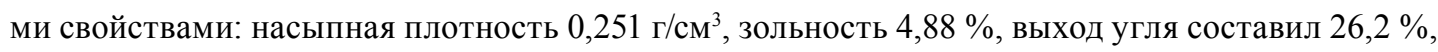
адсорбция йода 1043 мг/г, адсорбция метиленового синего 427 мг/г и удельная поверхность по BET $1239 \mathrm{~m}^{2} / \Gamma$.

Показана возможность использования активированного угля, полученного из коры эвкалипта методом активации фосфорной кислотой, в качестве эффективного сорбента для удаления тяжелых металлов из сточных вод.

В работе [66] карбонизованные угли, приготовленные из коры пальмы и эвкалипта, были использованы в качестве сорбентов для удаления красителя метиленового синего. Активные угли получали методом карбонизации измельченной коры при температуре $400{ }^{\circ} \mathrm{C}$ со скоростью нагрева $5{ }^{\circ} \mathrm{C} /$ мин и изотермической выдержкой в течение 30 мин. Полученные активные угли имеют хорошо развитую мезопористую структуру с удельной поверхностью 8-10 м²/г и средним диаметром пор 4,27-2,29 нм. Показана возможность использования карбонизованной коры пальмы и эвкалипта в процессах сорбции при очистке сточных вод от красителей.

\section{3. Перспективные направления в разработке способов получения пористых материалов из лигнина и коры}

Значительное количество патентов, опубликованных в период 2009-2014 гг., касается получения новых материалов с энтеросорбционными свойствами на основе лигнина. В ряде патентов предложены способы получения композиционных материалов на основе промышленно 
выпускаемых сорбционных материалов из гидролизного лигнина (так называемые медицинские или лечебные гидролизные лигнины). Так, в патенте [US 20090163427, опубл. 25.06.2009] предложено смешивать влажный медицинский гидролизный лигнин с водными растворами лактулозы и олигосахаридов (концентрация растворов 45 - 55 \%). Соотношение растворов добавок к энтеросорбенту варьируется от 10 до 60 мас. \%. Смешение компонентов проводят в роторном блендере при $30{ }^{\circ} \mathrm{C}$ в течение 20 мин. Далее возможно проводить гранулирование, таблетирование влажной массы [67]. В патентах [RU 2440121, опубл. 20.01.2012, ЕР 2486943, опубл. 15.08.2012, RU 2427389, опубл. 27.08.2011 и RU 2011108271, опубл. 10.09 2012] предложено смешивать сухие активные компоненты - медицинский гидролизный лигнин с пребиотиками различной природы или клетками штамма дрожжей Saccharomyces boulardii. Это позволяет получать композиции различного действия, в которых энтеросорбент и добавки усиливают взаимное позитивное действие [68-70].

В патенте [RU 2502319, опубл. 27.12.2013] предложен способ получения кормовой добавки, предназначенной для применения в ветеринарии, с использованием гидролизного лигнина. Смешение гидролизного лигнина с другими биоактивными добавками (клеточная стенка кормовых дрожжей, ферменты, минеральный сорбент) проводят в мельницах роторно-вихревого типа. Комплекс процессов, происходящих в результате механохимической активации компонентов, позволяет получать препарат с высокой связывающей активностью в отношении микотоксинов. Получаемая по предложенному способу кормовая добавка может быть рекомендована для профилактики микотоксикозов животных и птиц [71].

Основным недостатком вышеперечисленных патентов можно считать их направленность на использование гидролизного лигнина - традиционного сырья для получения медицинских лигнинов. В настоящее время в России наблюдается тенденция к сокращению объемов производства гидролизного лигнина, что обусловливает объективную возможность резкого сокращения выпуска энтеросорбентов на его основе. В условиях острого дефицита сырья такие патентные разработки могут потерять свою актуальность.

В патенте [WO 2009028969, опубл. 05.03.2009] предложен способ получения лигнина из различного растительного сырья, в том числе древесного (древесина тополя, эвкалипта, сосны и др.), который обладает антиоксидантными свойствами, антивирусной и антибактериальной активностью. Может использоваться в качестве эффективного энтеросорбента в медицине и ветеринарии. Лигнин предложено получать обработкой сырья 60-80\%-ным водным раствором этанола при температуре $170-210{ }^{\circ} \mathrm{C}$ и давлении 19-30 бар без каких либо катализаторов.

В патенте [RU 2477125, опубл. 10.03.2014] предложено модифицировать углеродный носитель бетулином, выделенным из коры березы. Это позволяет получить препарат с удельной поверхностью 170-250 м²/г, высокой адсорбирующей активностью и иммунокоррегирующим действием.

В патенте [RU 2471550, опубл. 10.01.2013] предложено получать лигниновые сорбенты, которые могут эффективно использоваться для энтеросорбции. Лигнин выделяли после обработкой древесных опилок смесью «уксусная кислота - вода - пероксид водорода - сернокислотный катализатор». Для получения энтеросорбентов лигнины предложено обрабатывать 0,4\%-ным раствором $\mathrm{NaHCO}_{3}$ при комнатной температуре в течение 15 мин. По сорбционной

$$
-245-
$$


активности полученные лигниновые сорбенты превосходят промышленный энтеросорбент марки «Полифепан».

Способ получения энтеросорбента из коры березы, согласно патенту [RU 2389498, опубл. 20.05.2010], включает обработку сырья 0,5 - 2 \% раствором щелочи при температуре $60-100^{\circ} \mathrm{C}$, гидромодуле $4-7$, в течение $30-60$ мин, промывку водой, нейтрализацию и сушку до воздушно-сухого состояния. Полученный сорбент по своим сорбционным свойствам не уступает промышленному аналогу из гидролизного лигнина марки «Полифепан». Запатентован способ получения энтеросорбента из коры березы [RU 2497537, опубл. 10.11.2013], включающий предварительную активацию сырья водяным паром в условиях взрывного автогидролиза и последующую обработку водным раствором щелочи. Введение стадии предварительной активации сырья позволяет получать энтеросорбент, который по сорбции метиленового синего и желатина существенно превосходит «Полифепан». Предлагаемые способы получения сорбентов обладают рядом неоспоримых достоинств. Они позволяют получать энтеросорбент на основе многотоннажного древесного отхода - коры березы, вывозимой большей частью в отвалы. В этом случае полностью ликвидируется зависимость производства от техногенного сырья, примером которого является гидролизный лигнин. Технологическая схема получения таких энтеросорбентов (патент $2389498 \mathrm{RU}$ ) принципиально практически не отличается от получения промышленного энтеросорбента «Полифепан» из гидролизного лигнина - оба способа имеют одинаковые стадии получения, где используются одинаковые реагенты и оборудование.

Анализ патентных данных показывает, что для получения нанопористых углеродных материалов используются следующие типы технических лигнинов: щелочные лигнины (образуются при варке древесины в растворах щелочей), лигносульфонаты (сульфитная варка древесины) и гидролизные лигнины (кислотный гидролиз древесины), а также композиции на их основе.

В патенте [RU 2521384 C2, C01B 31/02; C01B 31/08, опубл. 27.06.2014] пористый углеродный композиционный материал получают из растительного материала с добавкой лигнина и кремнийсодержащего компонента. Полученный углеродный материал можно использовать в качестве медицинского адсорбента, композиционного фотокаталитического материала, носителя для лекарственного препарата, агента, поддерживающего выделение лекарственного препарата, для селективной адсорбции нежелательных веществ в организме, насадки для колонн очистки крови, водоочищающего адсорбента.

В патенте [US 2014227325 A1, B01J20/20; В01J20/3078, опубл. 14.08.14] предложен способ получения пористого углерода, который включает предварительную стадию термического отжига композиции, состоящей из блок-сополимера и лигнина с последующей стадией карбонизации. Целью изобретения является получение состава пористого угля, имеющего объем мезопор не менее 50 \% по отношению к общему объему мезопор и микропор.

В патенте [US2014219909 A1, C01B 31/00; C01B 31/02; C07G31/100; D01F9/00; D01F9/17, опубл. 07.08.2014] предложен способ производства активированного пористого волокна из лигнина древесины хвойных пород и/или щелочного лигнина твердых пород лиственных деревьев. Лигниновое волокно подвергают дополнительной обработке, чтобы повысить пористость структуры углеродного волокна. 
В патенте [JP 2013147768 A, D01F9/00; D01F9/17, опубл. 01.08.2013] предложен способ производства активированного углеродного волокна, включающий этап получения производных лигнина, имеющих гидрофильные группы; этап формирования прекурсора волокна из производных лигнина путем прядения из расплава; этап придания неплавких свойств прекурсору волокна путем кислотной обработки; этап карбонизации и последующей активации углеродного волокна.

В патенте [US2014194603 A1, C08L97/02, опубл. 10.07.2014] предложен способ производства прекурсора для получения углеродных и активированных углеродных волокон с использованием влажного или воздушного прядения волокон, в соответствии с которым раствор лигнина и волокнообразующий полимер, растворенные в подходящем растворителе, экструдируют через отверстия фильеры в коагуляционную ванну, образовавшиеся нити растягивают и затем сушат при повышенной температуре.

В патенте [CN102350128 A, B01D39/02; B01D39/14, опубл. 15.02.2012 ] предложен способ получения активированного углеродного волокна и его использования в качестве фильтрующего элемента. Способ получения включает следующие стадии: смешивания порошка лигнина, кизельгура, каолина, меламина, полиэстера, клея, воды, золы соломы, вермикулита, природного цеолита, которые используются в качестве исходного сырья в определенном весовом соотношении, а также перемешивания, цементации и формирования или уплотнения и формирования, сушки и прокаливания при температуре $900-1300{ }^{\circ} \mathrm{C}$ с получением активированного углеродного волокна.

В патенте [US2014228460 A1, C08J91/228, опубл. 14.08.2014] предложен способ получения микропористого материала с использованием малоценных отходов бумажной промышленности, таких как промышленный лигнин. Полученный микропористый материал может быть применен для изготовления носителей катализаторов, фильтров и абсорбирующих элементов.

В патенте [RU2471550 C1, B01J20/24; B01J20/30, опубл. 10.01.2013] предложен способ получения сорбентов из лигнина для использования в медицине, ветеринарии, а также в пищевой и химической промышленности.

В патенте [KR20120117246 А, В01J20/20; B01J20/30; B09B3/00; C01B31/02, опубл. 24.10.2012] предложен способ получения пористых углеродных материалов из лигнина, который включает следующие этапы: подготовка лигнина; расплавление лигнина и его охлаждение, измельчение охлажденного лигнина; измельченный лигнин перемешивают в жидкости и нагревают для приготовления жидкой смеси; жидкую смесь охлаждают до отдельных частиц лигнина, разделенные частицы лигнина стабилизируют и активируют.

В патенте [CN102730681 А, C01B31/12, опубл. 17.10.2012] предложен способ получения активированного угля, который включает в себя смешивание лигнина соломы с водным раствором активатора (концентрации 25-50 \%), сушку при 105-120 ${ }^{\circ} \mathrm{C}$, карбонизацию и активацию при 600- $900{ }^{\circ} \mathrm{C}$ в течении 1-3 ч, обработку кипящей водой, сушку и измельчение. Полученный активированный уголь имеет большую удельную площадь поверхности, высокие адсорбционные свойства.

В патенте [CN102701201 A, C01B31/12, опубл. 03.10.2012] предложен способ получения порошкового активированного угля из щелочного лигнина натронной варки древесины. Способ

$$
-247-
$$


включает следующие этапы: экстрагирование лигнина из черного щелока путем подкисления. Смесь лигнина и КОН помещают в ультразвуковую ванну с водой и подвергают ультразвуковой обработке в течение 30-35 мин. После сушки смесь лигнина и гидроксида калия нагревают и активируют течение от 0,5 до 2,0 ч при 650 до $850{ }^{\circ} \mathrm{C}$ с тем, чтобы получить порошкообразный активированный уголь. Готовый активированный порошкообразный уголь имеет большую удельную площадь поверхности, высокую пористость и адсорбционные свойства и может эффективно удалить тяжелые металлы и органические загрязнители.

В патенте [JP2011162369 A, B01D15/00; B01J20/20; B01J20/30; C01B31/12; C07C29/76; C07C31/02; C02F1/28, опубл. 25.08.2011] предложен способ получения активированного угля с высокой удельной поверхностью для использования в качестве адсорбента при адсорбции и извлечении низших спиртов из растворов с низкой концентрацией. Для получения активированного угля лигнин пропитывают карбонатной солью щелочного металла, подвергают последующему нагреванию смеси в атмосфере инертного газа при температуре $\geq 700{ }^{\circ} \mathrm{C}$. Полученный активированный уголь имеет высокую удельную поверхность, высокий выход готового продукта и высокую активность при адсорбции низших спиртов.

В патенте [CN 101913603 А, С01B31/12, опубл. 15.10.2010] предложен способ получения активированного угля из древесной коры, предварительно обработанной в присутствии активирующего агента в ультразвуковой ванне.

В патенте [JP 2010222434 A, C08K3/00; C08L1/00; C08L101/00, опубл. 07.10.2010] предложен способ изготовления формованных активированных материалов на основе коры для применения в растениеводстве, демпфировании почвы, а также для теплоизоляции и звукоизоляции.

В ряде патентов [RU 2352349 C1, А61K36/185, опубл. 20.04.2009 и RU 2352350 C1, A61K36/185, опубл. 20.04.2009; RU 2400511 A, C09F1/00, опубл. 27.09.2010] описаны способы получения пористых углеродных сорбентов из остатков проэкстрагированной древесной коры. Так, в патенте [RU 2400511 A, C09F1/00, опубл. 27.09.2010] предложен способ переработки коры сосны, который включает экстракцию коры неполярным растворителем с извлечением хвойного воска, последующее выделение из коры пектина и переработку остатка коры в активный уголь. Предложенный способ позволяет достичь практически полной утилизации коры сосны с получением из нее хвойного воска, проантоцианидинов, пектина и активированного угля.

Авторами изобретения [RU 2352349 C1, A61K36/185 опубл. 20.04.2009 и RU 2352350 C1, А61K36/185, опубл. 20.04.2009] предложены способы получения углеродного сорбента из твердого остатка экстракции коры березы, который подвергают одностадийной карбонизацииактивации в реакторе кипящего слоя.

Таким образом, анализ патентной литературы позволяет выявить основные направления в разработке новых способов получения из лигнина и древесной коры энтеросорбентов, нефтесобирателей, нанопористых углеродных материалов. Традиционным сырьем для получения энтеросорбентов типа «Полифепан» является гидролизный лигнин. Сокращение его запасов вследствие закрытия гидролизных производств в России делает актуальным поиск новых источников сырья для получения энтеросорбентов. Доступным и дешевым ресурсом для этих целей является древесная кора. В частности, энтеросорбенты, полученные из березовой коры, не уступают, а по некоторым показателям превышают качество энтеросорбента «Полифепан» из гидролизного лигнина. 
Для получения нанопористых углеродных материалов из растительного сырья используется две группы методов: двухстадийная карбонизация - физическая активация и одностадийная химическая активация. Двухстадийные способы целесообразно использовать для получения нанопористых углеродных сорбентов из древесной коры, включая проэкстрагированную кору. Для получения нанопористых углеродных материалов из лигнина предпочтительным является использование химической активации гидроксидами натрия или калия.

\section{Список литературы}

1. Greiner, E., Kalin, T., Inoguchi, Y. Marketing Research Report: Activated Carbon, Chemical Economics Handbook. SRI Consulting, 2010. P. 5.

2. Marsh H., Rodríguez-Reinoso F. Activated Carbon. Amsterdam: Elsevier, 2006. 554 p.

3. Stewart D. Lignin as a base material for materials applications: Chemistry, application and economics. Industrial crops and products 2008. № 27. Р. 202-207.

4. Симонова В.В., Шендрик Т.Г., Кузнецов Б.Н. Методы утилизации технических лигнинов. Ж. Сиб. федер. ун-та. Химия 2010. Т. 3(4), С. 340-354. [Simonova V.V., Shendrik T.G., Kuznetsov B.N. Methods of Industrial Lignins Utilization. Journal of Siberian Federal University. Chemistry 2010. V. 3(4). P. 340-354. (In Russ.)]

5. Manimaran Ayyachamy, Finola E. Cliffe \& Jessica M. Coyne, Collier J., Tuohy M.G. Lignin: untapped biopolymers in biomass conversion technologies. Biomass Conv. Bioref. 2013. № 3. P. 255269.

6. Suhas S., Carrott P.J.M., Carrott M.M.L.R. Lignin - from natural adsorbent to activated carbon: A review. Biores. Technol. 2007. № 98. P. 2301-2312.

7. Sharma R.K., Wooten J.B., Baliga V.L., et al. Characterisation of chars from pyrolysis of lignin. Fuel 2004. № 83. P. 1469-1482.

8. Еремина А.О., Головина В.В., Чесноков Н.В., Кузнецов Б.Н. Углеродные адсорбенты из гидролизного лигнина для очистки сточных вод от органических примесей. Ж. Сиб. федер. ун-та. Химия 2011. T.4(1), C. 100-107. [Eremina A.O., Golovina V.V., Chesnokov N.V., Kuznetsov B.N. Carbon Adsorbents from Hydrolytic Lignin for Waste Waters Purification from Organic Contaminations. Journal of Siberian Federal University. Chemistry. 2011. V. 4(1). P. 11107. (In Russ.)]

9. Kijima M., Hirukawa T., Hanawa F., Hata T. Thermal conversion of alkaline lignin and its structured derivatives to porous carbonized materials. Biores. Technol. 2011. Vol. 102(10). P. 62796285.

10. Kuznetsov B.N., Shchipko M.L., Chesnokov N.V. Porous carbons obtained from lignite, anthracite and graphite in a bed of slag and catalyst particles. Journal of Siberian Federal University 2009. Vol. 2(2). P. 93-101.

11. Baklanova O.N., Plaksin G.V., Drozdov V.A., Duplyakin V.K., Chesnokov N.V., Kuznetsov B.N. Preparation of microporous sorbents from cedar nutshells and hydrolytic lignin. Carbon 2003. №. 41. P. 1793-1800.

12. Fu K., Yue Q., Gao B., et al. Preparation, characterization and application of lignin-based activated carbon from black liquor lignin by steam activation. Chem. Eng. J. 2013. Vol. 228(15). P. 1074-1082. 
13. Rodriguez-Mirasol J., Cordero T., Rodriguez J.J. Activated carbons from $\mathrm{CO}_{2}$ partial gasification of eucalyptus kraft lignin. Energy Fuels 1993. N 7. P. 133-138.

14. Бакланова О.Н., Плаксин Г.В., Дроздов В.А. Микропористые углеродные сорбенты на основе растительного сырья. Российский химический журнал 2004. T. 48(3), С. 89-94. [Baklanova O.N., Plaksin G.V., Drozdov V.A. Microporous carbon adsorbents based on vegetable raw materials. Russian Chemical Journal 2004. V. 48(3). P. 89-94. (In Russ.)]

15. Suhas, Carrott P.J.M., Carrott M.M.L.R. Using alkali metals to control reactivity and porosity during physical activation of demineralised Kraft lignin. Carbon 2009. № 47. P. 1012-1017.

16. Hayashi J., Kazehaya A., Muroyama K., Watkinson A.P. Preparation of activated carbons from lignin by chemical activation. Carbon 2000. N 38. P. 1873-1878.

17. Solange I. Mussatto, Marcela Fernandes, George J.M. Rocha, et al. Production, characterization and application of activated carbon from brewer's spent grain lignin. Biores. Technol. 2010. № 101. P. 2450-2457.

18. Maldhure A.V., Ekhe J. Preparation and characterizations of microwave assisted activated carbons from industrial waste lignin for Cu (II) sorption. Chem. Eng. J. 2011. № 168. P. 11031111.

19. Kriaa A., Hamdi N., Srasra E. Removal of Cu (II) from water pollutant with Tunisian activated lignin prepared by phospohoric acid activation. Desalination 2010. Vol. 250(1). P. 179-187.

20. Maldhure A.V., Ekhe J.D. Microwave treated activated carbon from industrial waste lignin for endosulfan adsorption. J. Chem. Technol. and Biotechnol. 2011. Vol. 86(8). P. 1074-1080.

21. Zhao X., Cao J., Sato K., et al. High surface area activated carbon prepared from black liquor in the presence of high alkaline metal content. J. Chem. Eng. Japan 2010. № 43. P. 1029-1034.

22. Белецкая М.Г., Богданович Н.И., Кузнецова Л.Н., Саврасова Ю.А. Методы термохимической активации в синтезе активных углей из технических лигнинов. Известия вузов. Лесной журнал 2011. №6, С. 125-132. [Beletskaya M.G., Bogdanovich N.I., Kuznetsova L.N., Savrasova Yu.A. Methods of thermochemical activation of the synthesis of active coals from technical lignins. Izvestia vuzov. Lesnoy zhurnal 2011. N 6. P. 125-132. (In Russ.)]

23. Белецкая М.Г., Богданович Н.И. Формирование адсорбционных свойств нанопористых материалов методом термохимической активации. Химия растительного сырья 2013. № 3. C. 77-82. [Beletskaya M.G., Bogdanovich N.I. Formation of the adsorption properties of nanoporous materials by a thermochemical activation. Khimija Rastitel'nogo Syr'ja 2013. N 3. P. 77-82 (In Russ.)]

24. Исмаилова М.Г. Влияние условий карбонизации на формирование пористой структуры активированного угля из хлопкового лигнина. Физикохимия поверхности и защита материалов 2009. T. 45(2), С. 228-231. [Ismailova M.G. Effect of conditions of carbonization on formation of the porous structure of activated carbon from cotton lignin. Phisikokhimia poverhnosti i zashhita materialov 2009. Vol. 45(2). P. 28-231. (In Russ.)]

25. Хитрин К.С., Хитрин С.В., Фукс С.Л., и др. Влияние физической и химической модификации на сорбционную способность гидролизного лигнина. Журн. прикл. химии. 2012. T. 85(8), C. 1258-1261. [Khitrin K.S., Khitrin S.V., Fuks S.L. et al. Influence of physical and chemical modification on the sorption capacity of hydrolytic lignin. Journal of Applied Chemistry. 2012. V. 85(8). P. 1258-1261. (In Russ.)] 
26. Опра Д.П., Гнеденков С.В., Синебрюхо Л.В, и др. Высокоэнергоемкие литиевые источники тока на основе гидролизного лигнина. Вестник ДВО РАН 2012. № 2, С. 111-116. [Opra D.P., Gnedikov S.V., Sinebryukho L.V. et al. High-energy lithium power sources on the basis of the hydrolysis lignin. Vestnik DVO RAN 2012. N 2. P. 111-116. (In Russ.)]

27. Микова Н.М., Чесноков Н.В., Иванов И.П., Кузнецов Б.Н. Изучение свойств нанопористых углеродных материалов, полученных щелочной активацией растительных полимеров. Сб. тр. Всерос. науч.-практ. конф. «Лесной и химический комплексы- проблемы и решения». Красноярск 2009, C. 391-397. [Mikova N.M., Chesnokov N.V., Ivanov I.P., Kuznetsov B.N. Studying the properties of nanoporous carbon materials obtained alkaline activation of plant polymers. Book of Proc. of Sci-Tech. Conf. "Forest and Chemical complexes - problems and solutions". Krasnoyarsk. 2009. P. 391-397. (In Russ.)]

28. Zazo J.A, Bedia J, Fierro C.M, et al. Highly stable Fe on activated carbon catalysts for CWPO upon $\mathrm{FeCl} 3$ activation of lignin from black liquors. Catal. Today 2012. Vol. 187(1), P.115-121.

29. Mahmoudi K., Hamdi N., Kriaa A., Srasra E. Adsorption of methyl orange using activated carbon prepared from lignin by $\mathrm{ZnCl} 2$ treatment. Russ. J. Phys. Chem. 2012. Vol. 86(8). P. 12941300.

30. Sun Y., Wei J., Wang Y., Yang G., Zhang J. Production of activated carbon by K2CO3 activation treatment of cornstalk lignin and its performance in removing phenol and subsequent bioregeneration. Environ Technol. 2010. Vol. 31(1). P. 53-61.

31. Sixiao Hu, Sanliang Zhang, Ning Pan, You-Lo Hsieh High energy density supercapacitors from lignin derived submicron activated carbon fibers in aqueous electrolytes. $J$. of Power Sources 2014. № 270. P. 106-112.

32. Carrott P.J.M., Carrott M.M.L.R. Comparison of the Dubinin-Radushkevich and Quenched Solid Density Functional Theory approaches for the characterisation of narrow microporosity in activated carbons obtained by chemical activation with $\mathrm{KOH}$ or $\mathrm{NaOH}$ of Kraft and hydrolytic lignins. Carbon 2010. № 48, P. 4162-4169.

33. Torné-Fernández V., Mateo-Sanz J., Montané D., Fierro V. Statistical optimization of the synthesis of highly microporous carbons by chemical activation of Kraft lignin with NaOH. J. Chem. Eng. Data 2009. №54. Р. 2216-2221.

34. Богданович Н.И., Короткий В.П., Великанов В.И., Носков Д.К. Переработка низкосортной и мелкотоварной древесины в энтеросорбенты для сельского хозяйства методом совмещенного процесса карбонизации - активации на модульных установках в полевых условиях. Известия вузов. Лесной журнал. 2010. №4. С. 126-131. [Bogdanovich N.I., Korotkiy V.P., Velikanov V.I., Noskov D.K. Processing of low-grade and small-scale timber in chelators for agriculture by the combined process of carbonization - activation of modular units in the field. Izvestiya vuzov. Lesnoy Zhurnal 2010. N 4. P. 126-131. (In Russ.)]

35. Канарская 3.А., Канарский А.В., Хабаров Ю.Г., и др. Адсорбция микотоксинов техническими лигнинами. Химия растительного сырья 2011. № 1. С. 59-63. [Kanarskaya Z.A., Kanrsky A.V., Khabarov Yu. G. et al. Adsorption of mycotoxins technical lignins. Khimja Rastitel'nogo Syr' ja 2011. N 1. P. 59-63. (In Russ.)], C. 33-39. [Andreev A.I., Selyanina S.B., Bogdanovich N.I. Sorption properties of hardwood and softwood sulphate lignins. Khimja Rastitel'nogo Syr' ja 2012. N 2. P. 33-39. (In Russ.)] 
36. Судакова И.Г., Кузнецов Б.Н., Гарынцева Н.В., Королькова И.В. Состав и связующие свойства лигнинов, полученных окислительной делигнификацией древесины пихты, осины и березы в среде уксусной кислоты. Химия растительного сырья 2010. № 3, C.55-60. [Sudakova I.G., Kuznetsov B.N., Garyntseva N.V., Korol'kova I.V. The composition and the binding properties of lignins derived oxidative delignification of fir, aspen and birch wood in acetic acid. Khimja Rastitel'nogo Syr' ja 2010. N 3. P. 55-60. (In Russ.)]

37. Гарынцева Н.В., Судакова И.Г., Кузнецов Б.Н. Свойства энтеросорбентов, полученных из уксуснокислотных лигнинов древесины пихты, осины и березы. Журнал Сиб. федер.. ун-та. Химия 2011. Т. 4(2). C.121-126. [Garyntseva N.V., Sudakova I.G., Kuznetsov B.N. Properties of Enterosorbents Obtained from Acetic Acid Lignins of Abies, Aspen and Birch Wood. Journal of Siberian Federal University 2011. V. 4(2). P. 121-126. (In Russ.)]

38. Веприкова Е.В., Кузнецова С.А., Чесноков Н.В., Кузнецов Б.Н. Свойства энтеросорбентов, полученных иммобилизацией фурацилина и желатина на пористой подложке из луба коры березы. Журнал Сиб. федер. ун-та. Химия 2014. T. 7(1). C. 100-111. [Veprikova E.V., Kuznetsova S.A., Chesnokov N.V., Kuznetsov B.N. Properties of Enterosorbents Obtained by Immobilization of Furacilin and Gelatin on the Porous Carrier from Inner Birch Bark. Journal of Siberian Federal University 2014. V. 7(1). P. 100-111. (In Russ.)]

39. Патент 2311954 РФ. Кузнецова С.А., Щипко М.Л., Кузнецов Б.Н., Ковальчук Н.М., Веприкова Е.В., Лезова А.А. Энтеросорбент и способ его получения. Опубл. 10.12.2007. [Patent 2311954 RU. Kuznetsova S.A., Sshipko M.L., Kuznetsov B.N., Kovalchuk N.M., Veprikova E.V., Lezova A.A. Enterosorbent and method of its receiving. Publ. Date 10.12.2007. (In Russ.)]

40. Патент 2389498 РФ. Кузнецова С.А., Кузнецов Б.Н., Ковальчук Н.М., Скворцова Г.П. Энтеросорбент. Опубл. 20.05.2010. [Patent 2389498 RU. Kuznetsova S.A., Kuznetsov B.N., Kobalchuk N.M., Skvortsova G.P. Enterosorbent. Publ. Date 20.05.2010. (In Russ.)]

41. Коптина А.В., Шургин А.И., Канарский А.В. Использование коры Salix acutifolia для получения салицилатов. Растительные ресурсы 2010. №1, С. 67-71. [Koptina A.V., Shurgin A.I., Kanarsky A.V. Using bark Salix acutifolia for salicylates. Rastitel'nye Resursy 2010. N. 1. P. 67-71. (In Russ.)]

42. Коптина А.В., Шургин А.И., Канарский А.В., и др. Эффективность адсорбции Т-2 микотоксина корой ивы Salix acutifolia. Известия вузов. Лесной журнал. 2009. № 6. С. 145-148. [Koptina A.V., Shurgin A.I., Kanarsky A.V. The effectiveness of adsorption of T-2 mycotoxin bark of willow Salix acutifolia. Izvestiya vuzov. Lesnoy zhurnal 2009. N 6. P. 145-148. (In Russ.)]

43. Веприкова Е.В., Кузнецова С.А., Чесноков Н.В., Кузнецов Б.Н. Свойства энтеросорбентов, полученных из автогидролизованной коры березы. Химия в интересах устойчивого развития. 2012. Т. 20(6). С. 673-678. [Veprikova E.V., Kuznetsova S.A. Chesnokov N.V., Kuznetsov B.N. Properties of Enterosorbents Obtained from Autohydrolyzed Bark. Chemistry for Sustainable Development 2012. Vol. 20(6). P. 621-626. (In Russ.)]

44. Каменщиков Ф.А., Богомольный Е.И. Нефтяные сорбенты. М.: Ижевск. Институт компьютерных исследований, 2003.268 с. [Kamensshikov F.A., Bogomol'ny E.I. Oil sorbents. Moscow: Izhevsk. Institute of Computer Science, 2003. 268 p. (In Russ.)]

45. Каменщиков Ф.А., Богомольный Е.И. Удаление нефтепродуктов с водной поверхности и грунта. М. - Ижевск. Институт компьютерных исследований, 2006. 528 с. [Kamensshikov 
F.A., Bogomol'ny E.I. Removal of oil from the water surface and soil. Moscow: Izhevsk. Institute of Computer Science, 2006. 528 p. (In Russ.)]

46. Самойлов Н.А., Хлесткин Р.Н., Шеметов А.В. и др. Сорбционный метод ликвидации аварийных разливов нефти и нефтепродуктов. М.: Химия, 2001. 189 с. [Samoylov N.A., Khlestkin R. N., Shemetov A.V. et al. Sorption methods of oil spill response and oil. Moscow: Khimia, 2001. 189 p. (In Russ.)]

47. Бордунов В.В., Коваль Е.О., Соболев И.А. Полимерные волокнистые сорбенты для сбора нефти. Нефтегазовые технологии. 2000. № 6, C. 30-31. [Bodunov V.V., Koval E.O., Sobolev I.A. Polymeric fibrous sorbents for oil collection. Neftegazovye Tekhnologii 2000. N. 6. P. 30-31. (In Russ.)]

48. Семенович А.В., Лоскутов С.Р. Адсорбция катионных красителей модифицированной корой древесных пород. Химия растительного сырья. 2004. № 3, С. 121-125. [Semenovich A.V., Loskutov S.R. The adsorption of cationic dyes by modified bark of trees. Khimija Rasitel'nogo Syr'ja 2004. N 3. P. 121-125. (In Russ.)]

49. Хохлова А.П. Адсорбция тяжелых металлов сорбентом на основе сосновой коры. Химия и технология водыл. 2010. Т. 32(6). С. 604-612. [Khokhlova A.P. Adsorption of heavy metal sorbents based on pine bark. Khimiya i Technologiya vody 2010. Vol. 32(6). P. 604-612. (In Russ.)]

50. Веприкова Е.В., Терещенко Е.А., Чесноков Н.В., Кузнецов Б.Н. Использование бересты коры для получения сорбционных материалов // Журнал Сиб. федер. ун-та 2012. Т. 5(2), С. 178188. [Veprikova E.V., Teresshenko E.A., Chesnokov N.V., Kuznetsov B.N. Utilization of Outer Birch Bark for Sorption Materials Produce. Journal of Siberian Federal University 2012. Vol. 5(2). P. 178188. (In Russ.)]

51. Веприкова Е.В., Терещенко Е.А., Щипко М.Л. и др. Сорбенты для ликвидации нефтяных загрязнений, полученные автогидролизом древесных отходов. Экология и промышленность России 2011. Июнь, С. 16-20. [Veprikova E.V., Teresshenko E.A., Sshipko M.L. et al. Sorbents for elimination of oil pollution, obtained by autohydrolysis of waste wood. Ekologiya i Promyshlennost Rossii 2011. June. P. 16-20. (In Russ.)]

52. Веприкова Е.В., Терещенко Е.А. Оптимизация процесса получения нефтяных сорбентов из отходов окорки осины. Химия растительного сырья. 2013. №2. С. 219-222. [Veprikova E.V., Teresshenko E.A. Optimization of the process of obtaining of oil sorbents from waste aspen debarking. Khimija Rastitel'nogo Syr' ja 2013. N 2. P. 219-222. (In Russ.)]

53. Артемов А.В., Пинкин А.В. Сорбционные технологии очистки воды от нефтяных загрязнений. Вода: химия и экология. 2008. № 1. С. 19-25. [ Artemov A.V., Pinkin A.V. Sorption technology of water purification from oil pollution. Voda: Khimiya I ekologiya 2008. N 1. P. 19-25. (In Russ.)]

54. Бордунов В.В., Бордунов С.В., Леоненко В.В. Очистка воды от нефти и нефтепродуктов. Экология и промышленность России 2005. № 8, C. 8-11. [Bordunov V.V., Bordunov S.V., Leonenko V.B. Water purification from oil and oil products. Ekologiya I Promyshlennost Rossii 2005. N 8. P. 8-11. (In Russ.)]

55. Веприкова Е.В., Терещенко Е.А., Чесноков Н.В. и др. Волокнистые древеснополистирольные сорбенты для ликвидации нефтяных загрязнений. Журнал Сиб. федер. ун- 
ma. 2011. 4(1), C. 27-37. [Veprikova E.V., Teresshenko E.A., Chesnokov N.V. Wood - Polystirol Fiber Sorbents for Elimination of Oil Pollutions. Journal of Siberian Federal University 2011. Vol. 4(1). P. 27-37. (In Russ.)]

56. Рудковский А.В., Щипко М.Л., Головина В.В. и др. Получение активных углей из коры пихты и остатков ее экстракционной переработки. Химия растительного сырья. 2003. № 1 . C. 97-100. [Rudkovsky A.V., Sshipko M.L., Golovina V.V. et al. Khimija Rastitel'nogo syr'ja 2003. N 1. P. 97-100. (In Russ.)]

57. Беседина И.Н., Симкин Ю.Я., Петров В.С. Получение углеродных материалов из отходов сухой окорки лиственницы сибирской. 3. Получение активных углей. Химия растительного сырья 2002. № 2, С. 71-74. [Besedina I.N., Simkin Yu. Ya., Petrov V.S. Preparation of carbon materials from the waste dry debarking Siberian larch. 3. Preparation of activated carbons. Khimija Rastitel'nogo syr' ja 2002. N 2. P. 71-74. (In Russ.)]

58. Симкин Ю.Я., Беседина И.Н. Формирование пористой структуры активных углей из брикетов сухой окорки лиственницы сибирской. Химия растительного сырья. 2009. № 2 , C. 131-134. [Simkin Yu. Ya., Besedina I.N. The formation of the porous structure of activated carbons from briquettes dry debarking Siberian larch. Khimija Rastitel'nogo syr'ja 2009. N 2. P. 131-134. (In Russ.)]

59. Беседина И.Н., Симкин Ю.Я., Петров В.С. Получение углеродных материалов из отходов сухой окорки лиственницы сибирской. 1. Особенности отходов сухой окорки как сырья для получения углеродных материалов. Химия растительного сырья. 2002. № 2. С. 6366. [Besedina I.N., Simkin Yu. Ya., Petrov V.S Preparation of carbon materials from the waste dry debarking Siberian larch. Features 1. Dry debarking of waste as raw material for the production of carbon materials. Khimija Rastitel'nogo syr' ja 2002. N 2. P. 63-66. (In Russ.)]

60. Кузнецов Б.Н., Головин Ю.Г., Головина В.В. и др. Получение углеродных сорбентов из продуктов экстракционной переработки коры лиственницы сибирской. Химия растительного сырья 2002. № 2, C. 57-61. [Kuznetsov B.N., Golovin Yu.G., Golovina V.V. Production of carbon sorbents from the products extraction processing Siberian larch bark. Khimija Rastitel'nogo syr'ja 2002. N 2. P. 57-61. (In Russ.)]

61. Иванов И.П., Судакова И.Г., Иванченко Н.М. и др. Изучение свойств активных углей из зерненой коры лиственницы. Химия растительного сырья. 2011. № 1, С. 81-86. [Ivanov I.P., Sudakova I.G., Ivanchenko N.M. ey al. Studying the properties of activated carbons from graining larch bark. Khimija Rastitel'nogo syr'ja 2011. N 1. P. 81-86. (In Russ.)]

62. Yong Xiao, Hanwu Dong, Chao Long et. al. Melaleuca bark based porous carbons for hydrogen storage. International Journal of Hydrogen Energy. 2014. Vol. 39(22). P. 11661-11667.

63. Phussadee Patnukao, Apipreeya Kongsuwan, Prasert Pavasant. Batch studies of adsorption of copper and lead on activated carbon from Eucalyptus camaldulensis Dehn. bark. Journal of Environmental Sciences. 2008. Vol. 20(20). P. 1028-1034.

64. Patnukao P., Pavasant P. Activated carbon from Eucalyptus camaldulensis Dehn bark using phosphoric acid activation. Biores Technol. 2008. Vol. 99(17). P. 8540-8543.

65. Apipreeya Kongsuwan, Phussadee Patnukao, Prasert Pavasant. Binary component sorption of $\mathrm{Cu}(\mathrm{II})$ and $\mathrm{Pb}$ (II) with activated carbon from Eucalyptus camaldulensis Dehn bark. J. of Industrial and Engineering Chemistry. 2009. N 15. P. 465-470. 
66. Lei Sun, Shungang Wana, Wensui Luo. Biochars prepared from anaerobic digestion residue, palm bark, and eucalyptus for adsorption of cationic methylene blue dye: Characterization, equilibrium, and kinetic studies. Bioresource Technology. 2013. N 140. P. 406-413.

67. Patent 20090163427 US. Dikovskiy A.V. Pharmaceutical composition of enterosorbent and prebiotics, dosage forms, and the method for prevention and treatment of gastrointestinal disorders. Publ. Date 25.06.2009.

68. Патент 2440121 РФ. Диковский А.В., Третьяков С.В., Турчев О.А. Ветеринарная фармацевтическая композиция и способ (варианты) профилактики и лечения заболеваний ЖКТ и интоксикаций различной этиологии у животных Опубл. 20.01.2012. [Patent 2440121 RU. Dikivsky A.V., Tret'jakov S.V., Turchev O.A. Veterinary pharmaceutical compositions and methods (variants) for prevention and treatment of gastrointestinal diseases and intoxications of different etiologies in animals. Publ. Date 20.01.2012 (In Russ.)]

69. Patent 2486943 EP. Rudoi B.A.; Dikovskiy A.V. Pharmaceutical composition for the prophylaxis and treatment of infectious and non-infectious diarrhea. Publ. Date 15.08.2012.

70. Патент РФ 2427389. Диковский А.В., Рудой Б.А. Фармацевтическая композиция для профилактики и лечения инфекционных и неинфекционных диарей. Опубл. 27.08.2011. [Patent 2427389 RU. Dikovskiy A.V.Rudoi B.A. Pharmaceutical composition for the prevention and treatment of infectious and non-infectious diarrhea. Publ. Date 27.08.2011. (In Russ.)]

71. Патент 2502319 РФ. Косарев К.Л., Морозов А.М., Набиуллин А.Ш., Румянцев С.Д. Способ получения кормовой добавки для профилактики микотоксикозов у животных и птицы. Опубл. 27.12.2013. [Patent 2502319 RU. Kosarev K.L., Morozov A.M., Nabiullin A.Sh., Rumyantsev S.D. Method for producing a feed additive for preventing of mycotoxicoses at animals and birds. Publ. Date 27.12.2013. (In Russ.)] 